Polymer Journal, Vol. 25, No. 10, pp 1069-1077 (1993)

\title{
Anti-AIDS Virus Activity in Vitro of Dextran Sulfates Obtained by Sulfation of Synthetic and Natural Dextrans
}

\author{
Takashi Yoshida $^{\dagger \dagger}$, Hideki Nakashima*, Naoki Yamamoto*, \\ and Toshiyuki URYU ${ }^{\dagger}$ \\ Institute of of Industrial Science, University of Tokyo, \\ Roppongi, Minato-ku, Tokyo 106, Japan \\ *Tokyo Medical and Dental University School of Medicine, \\ Yushima, Bunkyo-ku, Tokyo 113, Japan
}

(Received March 17, 1993)

\begin{abstract}
Anti-AIDS virus activity of synthetic and natural dextran sulfates was assayed in vitro by using a MT-4 cell line. These dextran sulfates with the number average molecular weight $\left(\bar{M}_{n}\right)$ of $1.8 \times 10^{4}-10.7 \times 10^{4}$ showed potent anti-AIDS virus activity in the concentration as low as 3.3 or $10 \mu \mathrm{g} \mathrm{ml}^{-1}$, respectively. This high activity was almost the same as that of curdlan sulfates which was reported previously. The degree of sulfation per glucose residue in polymer backbone was 1.0-1.9 (the highest theoretical value is 3.0) which was calculated from the elemental analysis. The relationship between the structure and anti-AIDS virus activity is discussed based on high resolution NMR spectroscopy.
\end{abstract}

KEY WORDS Ring-Opening Polymerization / Sulfated Polysaccharide / Synthetic Dextran / Anti-AIDS Virus Activity / Anticoagulant Activity /

Dextran is a naturally occurring polysaccharide consisting of $1,6-\alpha$ linked poly-Dglucose and having branches depending on the strain. Dextran sulfate ${ }^{1}$ is a sulfated polysaccharide with a high negative charge which binds strongly to thrombin and shows anticoagulant activity. ${ }^{2}$ Since dextran sulfate has also lipemea-clearing activity, it has been clinically used for the treatment of high blood-lipid levels in Japan.

We successively synthesized stereoregular polysaccharides with biological activities by the ring-opening polymerization of anhydro sugars. ${ }^{3}$ Synthetic dextran by the ring-opening polymerization of 1,6 -anhydro- $\alpha$-D-glucose derivatives has only a straight-chained structure. ${ }^{4,5}$ We also reported the sulfation of synthetic dextrans with 3-O-( $\beta$-D-glucopyranosyl) or 3-
$O$-(- $\alpha$-D-mannopyranosyl) branches. ${ }^{6,7}$ Naturally occurring $\mathrm{N} 4$ dextran elaborated by $L$. mesonteroides strain $\mathrm{N} 4$ has been shown to have immunological specificity of 1,6- $\alpha$-Dglucosidic linkages. We reported that the synthetic mannose-branched dextrans reacted with $\mathrm{N} 4$ dextran-concanavalin A conjugate to form antibodies in rabit. ${ }^{8}$

It was found that dextran sulfate was effective for protection against scrapie virus in vivo experiment using mice ${ }^{9}$ and has an inhibitory effect on retroviruses ${ }^{10}$ and AIDS (acquired immunodeficiency syndrome) virus (HIV) infection in vitro. ${ }^{11-18}$ In this study, we report that synthetic and naturally occurring dextrans were sulfated with piperidine $N$ sulfonic acid in DMSO to give dextran sulfates which showed highly inhibitory effects on

\footnotetext{
+ To whom correspondence should be addressed.

${ }^{\dagger \dagger}$ Present address: Division of Biological Sciences, Graduate School of Science, Hokkaido University, Kita-ku, Sapporo 060, Japan.
} 
AIDS virus infection in vitro. The structural analysis of dextran sulfates using high resolution NMR experiments was made to correlate in detail the structures of linear and branched dextran sulfates with the anti-AIDS activity.

\section{EXPERIMENTAL}

\section{General Methods}

$270 \mathrm{MHz}{ }^{1} \mathrm{H}$ and $67.8 \mathrm{MHz}{ }^{13} \mathrm{C}$ NMR spectra were recorded with a JEOL GX-270 spectrometer for solutions in $\mathrm{CDCl}_{3}$ or $\mathrm{D}_{2} \mathrm{O}$. A solution of the free and sulfated dextrans in $\mathrm{D}_{2} \mathrm{O}$ was freeze-dried several times and a sample solution was made as $10-20 \%$ solution in $\mathrm{D}_{2} \mathrm{O}$ containing DSS (4,4-dimethyl-4silapentane-1-sulfonate) as the internal reference $\left(0.015 \mathrm{ppm}\right.$ for ${ }^{1} \mathrm{H}$ and $0.00 \mathrm{ppm}$ for ${ }^{13} \mathrm{C}$ spectra). Specific rotation was measured for solution in $\mathrm{CHCl}_{3}$ or $\mathrm{H}_{2} \mathrm{O}$ by a Perkin-Elmer 241 polarimeter. Molecular weight was determined by GPC and calculated with polystyrene and dextran standards as references for THF soluble and water soluble samples, respectively.

\section{Compounds}

1,6-Anhydro-2,3,4-tri- $O$-benzyl- $\beta$-Dglucopyranose (LGTBE) and 1,6-anhydro-2,4di- $O$-benzyl-3- $O$-tert-butyldimethylsilyl- $\beta$-Dglucopyranose (LGDBS) were prepared by the protection of 1,6-anhydro- $\beta$-D-glucopyranose according to the previous methods. ${ }^{5,6}$

\section{Polymerization}

Polymerization was performed under high vacuum in sealed glass ampoules as described in the previous paper. ${ }^{19}$ Polymerization conditions are shown in Table I. Polymers were purified by reprecipitation using chloroform-methanol system and then freeze-dried from benzene.

\section{Deprotection}

Desilylation $^{20}$ of polymers was carried out with tetrabutylammonium fluoride in THF under reflux for $1 \mathrm{~h}$ to give partially benzylated dextrans. The debenzylation of fully-benzylated linear dextrans was performed with sodium in liquid ammonia. ${ }^{19}$

\section{Branching of Partially Benzylated Dextrans}

To a partially benzylated dextran $(0.2 \mathrm{~g})$ solution in benzene $(40 \mathrm{ml})$ was added 3,4,6-tri- $O$-acetyl- $\alpha$-D-mannose 1,2-(methyl orthoacetate) $(0.25 \mathrm{~g})$. After the reaction mixture was heated at the boiling temperature $\left(\sim 80^{\circ} \mathrm{C}\right)$ for $15 \mathrm{~min}$, the solvent was partially distilled to remove a small amount of water as benzene azeotrope and then 2,6-lutidinium perchlorate $(1.5 \mathrm{mg})$ was added. The mixture was stirred under reflux for $20 \mathrm{~min}$, and then dried up by evaporation. The product was purified by reprecipitation of the chloroform solution with methanol, followed by freeze-drying from benzene; yield, $0.30 \mathrm{~g},[\alpha]_{\mathrm{D}}^{25}=+134.8^{\circ}(c=1$, $\left.\mathrm{CH}_{3} \mathrm{Cl}\right), \bar{M}_{n}=3.7 \times 10^{4}$.

\section{Sulfation of Free Dextrans}

To a linear dextran $(0.10 \mathrm{~g})$ solution in $15 \mathrm{ml}$ of dry DMSO was added piperidine $N$-sulfonic acid $(0.51 \mathrm{~g})$. The reaction mixture was stirred at $85^{\circ} \mathrm{C}$ for $1 \mathrm{~h}$. After cooling with an ice-bath, it was neutralized with saturated sodium bicarbonate solution, and then acetone was added to the mixture until a precipitate was appeared. The precipitate was collected by centrifugation, washed with acetone three times, redissolved in water $(c a .60 \mathrm{ml})$, and then dialyzed against deionic water overnight. The dialyzate was concentrated to $c a .20 \mathrm{ml}$ solution and freeze-dried to give dextran sulfate. Yield was $0.19 \mathrm{~g}$. The sulfur content and number average molecular weight of the dextran sulfates are shown in Table III.

\section{Anti-AIDS Virus Activity}

Anti-AIDS virus activity of the compounds against human immunodeficiency virus HIV-1 was determined by the inhibition of virusinduced cytopathic effects on MT-4 cells and 
virus-specific antigen detected on MT-4 cell surface. ${ }^{15}$ In the 3- and 6-day cultures of MT-4 cells after HIV infection, the number of viable cells and percentage of virus antigen-positive cells were measured by the trypan blue dye exclusion method and indirect immunofluorescence (IF), respectively.

\section{RESULTS}

\section{Synthesis of Free Dextran}

A stereoregular dextran was prepared by cationic ring-opening polymerization of tri$O$-benzylated 1,6-anhydro-glucopyranose LGTBE at $-60^{\circ} \mathrm{C}$ with phosphorus penta- fluoride as catalyst and subsequent debenzylation. The ring-opening polymerization of di- $O$-benzylated and 3-O-silylated monomer LGDBS was carried out by the same procedure as above to give the 3-O-silylated dextran derivative. Table I shows the results of the polymerizations. The polymers showed large and positive specific rotations, suggesting the polymers to have $\alpha$-stereoregularity. The number average molecular weight was $13.2 \times$ $10^{4}$ for the tri- $O$-benzylated polymer and $3.7 \times$ $10^{4}$ for the 3-O-silylated polymer, respectively. It was found that the ${ }^{13} \mathrm{C} \mathrm{NMR}$ spectra of the polymers showed high stereoregularity because of the appearance of a single absorption at

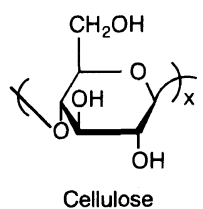

Cellulose

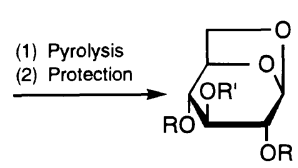

$1 \mathrm{R}=\mathrm{R}^{\prime}=\mathrm{Bn}$ $2 R=B n, R^{\prime}=t B D M S$

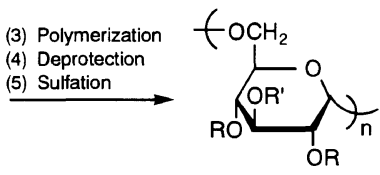

$3 \mathrm{R}=\mathrm{R}^{\prime}=\mathrm{Bn}$ $4 R=B n, R^{\prime}=$ tBDMS $5 \mathrm{R}=\mathrm{R}^{\prime}=\mathrm{H}$ $6 \mathrm{R}=\mathrm{Bn}, \mathrm{R}^{\prime}=\mathrm{H}$ $7 \mathrm{R}=\mathrm{R}^{\prime}=\mathrm{H}$ or $\mathrm{SO}_{3} \mathrm{Na}$

(n)

6

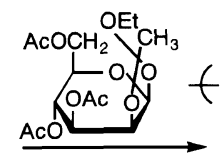


$97.0 \mathrm{ppm}$ due to the $\mathrm{Cl}$ peak having $\alpha$ stereoregularity (Figure 1B). Desilylation of poly(LGDBS) with tetrabutylammonium fluoride in tetrahydrofuran (THF) afforded 2,4-di- $O$-benzyl-( $1 \rightarrow 6)$ - $\alpha$-D-glucopyranan, which was reacted with 3,4,6-tri- $O$-acetyl- $\alpha$-Dmannose-1,2-(methyl orthoacetate) in benzene to give a mannose-branched dextran derivative. In the anomeric region of the mannose-

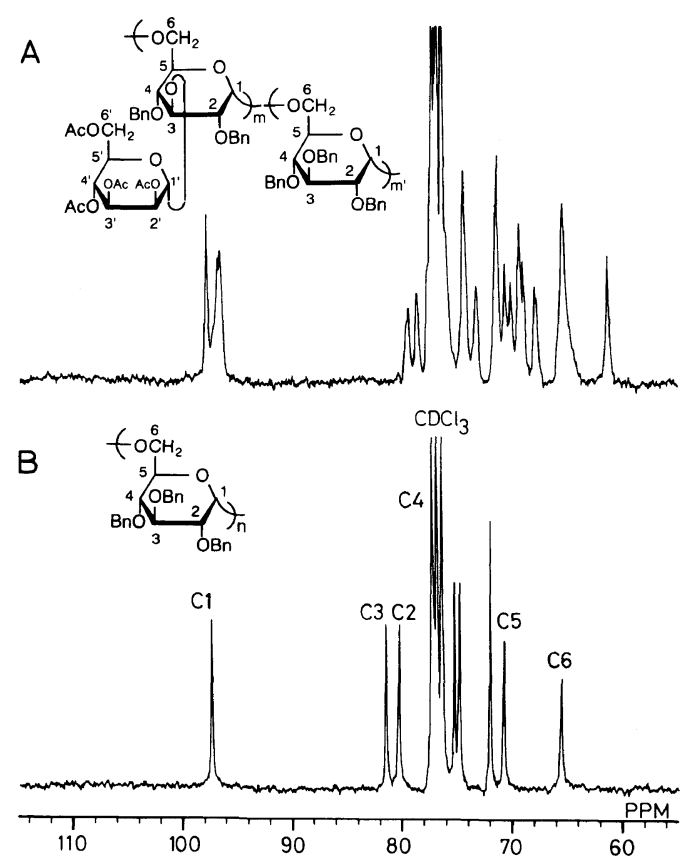

Figure 1. $67.8 \mathrm{MHz}{ }^{13} \mathrm{C} \mathrm{NMR}$ spectra of (A) benzylated dextran with mannose-branches and (B) benzylated linear dextrans $\left(\mathrm{CDCl}_{3}\right.$ as solvent). branched polymer (Figure 1A), two peaks appeared at 97.0 and $96.0 \mathrm{ppm}$. A new broad peak at $96.0 \mathrm{ppm}$ should be ascribed to the $\mathrm{Cl}$ absorption of the mannose-branches. By comparison with the integration value of $\mathrm{Cl}$ and $\mathrm{C} 6$ absorptions of the two units, respectively, the degree of mannose-branching was estimated to be $40 \%$, which was the highest of all the branched synthetic polysaccharides. ${ }^{3}$

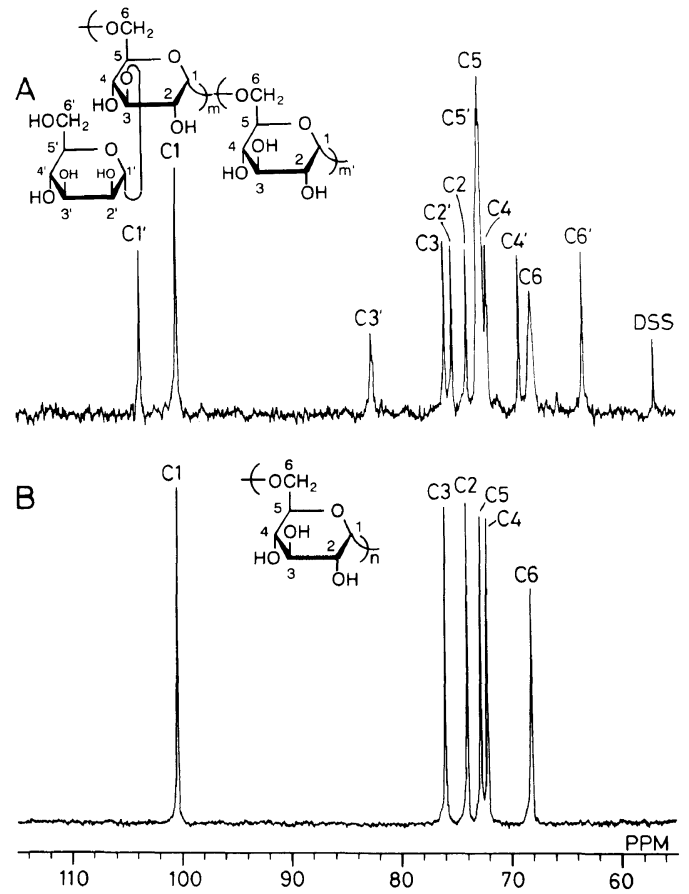

Figure 2. $67.8 \mathrm{MHz}{ }^{13} \mathrm{C} \mathrm{NMR}$ spectra of (A) mannosebranched and (B) linear dextrans $\left(\mathrm{D}_{2} \mathrm{O}\right.$ as solvent at $\left.37^{\circ} \mathrm{C}\right)$.

Table II. Deprotection of benzylated dextrans

\begin{tabular}{|c|c|c|c|c|c|c|c|c|}
\hline \multicolumn{4}{|c|}{ Benzylated dextran } & \multicolumn{5}{|c|}{ Free dextran } \\
\hline \multirow{2}{*}{\multicolumn{2}{|c|}{ No. }} & {$[\alpha]_{\mathrm{D}}^{25}$} & $\bar{M}_{n}$ & Yield & {$[\alpha]_{D}^{25 a}$} & $\bar{M}_{n}^{\mathrm{b}}$ & Stereoreg & arity $^{\mathbf{c}}$ \\
\hline & & $\operatorname{deg}$ & $\times 10^{4}$ & $\%$ & deg & $\times 10^{4}$ & & $\%$ \\
\hline 1 & (Linear) & +115.9 & 13.2 & 89 & +176.8 & 10.8 & $(1 \rightarrow 6)-\alpha$ & 100 \\
\hline 2 & $\begin{array}{l}\text { (50\% Mannose- } \\
\text { branched) }\end{array}$ & +134.9 & 5.5 & 85 & +155.6 & 1.8 & $(1 \rightarrow 6)-\alpha$ & 100 \\
\hline
\end{tabular}

a Measured in water $(c=1)$.

b Determined by GPC.

c Calculated by ${ }^{13} \mathrm{C}$ NMR spectrum. 
The deprotection of the linear and branched polymers with sodium in liquid ammonia gave free dextrans in 89 and $85 \%$ yields, respectively, as shown in Table II. The specific rotation of the free dextrans exhibited large positive values, $+176.8^{\circ}$ and $+155.6^{\circ}$, and the $\mathrm{Cl}$ absorption appeared at $100.6 \mathrm{ppm}$ as a single peak in the ${ }^{13} \mathrm{C}$ NMR spectra (Figure 2), suggesting that the free dextrans had complete 1,6- $\alpha$-stereoregularity. Assignments of the ${ }^{13} \mathrm{C}$ peaks (Figure 2B) have been established by Gagnaire and Vignon. ${ }^{21}$ In Figure 2A, the absorption of the mannose-branches appeared clearly at $104.0 \mathrm{ppm}\left(\mathrm{Cl}^{\prime}\right), 82.79\left(\mathrm{C}^{\prime}\right), 75.4\left(\mathrm{C}^{\prime}\right)$, $73.4-72.2\left(\mathrm{C}^{\prime}\right), 69.3\left(\mathrm{C}^{\prime}\right)$, and $63.4 \mathrm{ppm}$ $\left(\mathrm{C6}^{\prime}\right)$.

\section{Sulfation of Synthetic and Natural Dextrans}

Table III summarizes the results of sulfation. The free synthetic dextrans were sulfated with piperidine $\mathrm{N}$-sulfonic acid in dimethyl sulfoxide (DMSO) to give linear dextran sulfates and mannose-branched dextran sulfate, respectively. Natural branched dextrans, NRRL B-742 (No. 5 and 6) and B-512F (No. 7), were
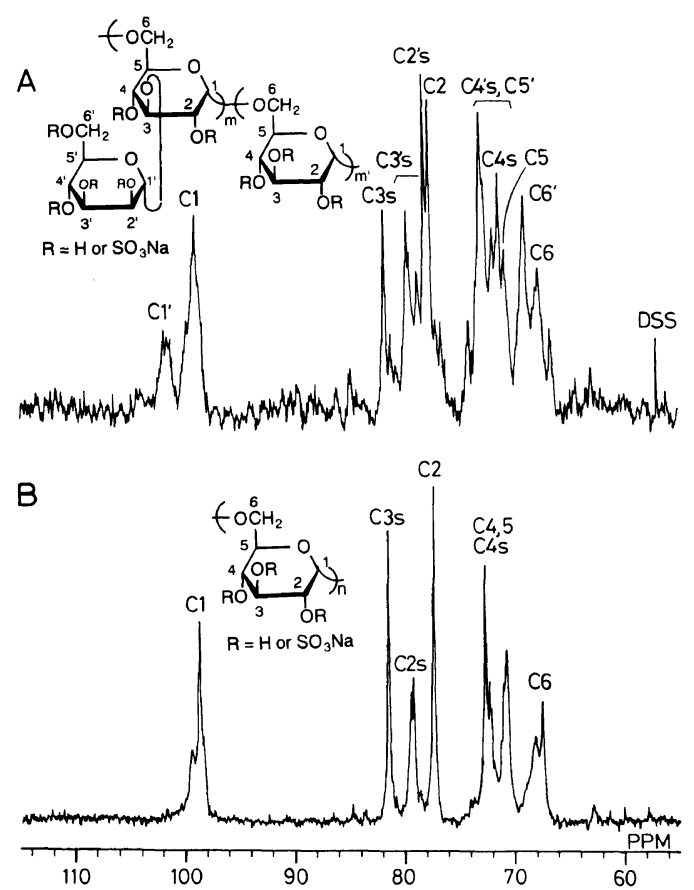

Figure 3. $67.8 \mathrm{MHz}{ }^{13} \mathrm{C}$ NMR spectra of (A) mannosebranched dextran sulfate (No. 4 in Table III) and (B) linear dextran sulfate (No. 3 in Table III) $\left(\mathrm{D}_{2} \mathrm{O}\right.$ as solvent at $37^{\circ} \mathrm{C}$ ). s, sulfate substituted carbon.

Table III. Sulfation of synthetic and natural dextrans

\begin{tabular}{|c|c|c|c|c|c|c|c|c|c|c|}
\hline \multirow{2}{*}{\multicolumn{2}{|c|}{ Polymer }} & \multirow{4}{*}{$\frac{\text { DMSO }}{\mathrm{ml}}$} & \multirow{4}{*}{$\frac{\mathrm{PSA}^{\mathrm{a}}}{\mathrm{g}}$} & \multirow{4}{*}{$\frac{\text { Yield }}{\mathrm{g}}$} & \multirow{4}{*}{$\frac{[\alpha]_{\mathrm{D}}^{25 b}}{\operatorname{deg}}$} & \multirow{4}{*}{$\frac{\bar{M}_{n}^{\mathrm{c}}}{\times 10^{4}}$} & \multicolumn{3}{|c|}{ Elemental analysis } & \multirow{4}{*}{$D S^{\mathrm{d}}$} \\
\hline & & & & & & & & & & \\
\hline \multirow[t]{2}{*}{ No. } & \multirow{2}{*}{ g } & & & & & & & & & \\
\hline & & & & & & & \multicolumn{3}{|c|}{$\%$} & \\
\hline \multicolumn{11}{|l|}{ Synthetic } \\
\hline 1 SDS-1 & 0.10 & 15 & 0.51 & 0.17 & +108.5 & 4.0 & 18.77 & 3.04 & 12.4 & 1.0 \\
\hline 2 SDS-2 & 0.13 & 20 & 0.30 & 0.21 & +127.3 & 4.2 & 23.06 & 3.85 & 12.4 & 1.2 \\
\hline 3 SDS-3 & 0.10 & 15 & 0.51 & 0.19 & +105.2 & 1.8 & 18.58 & 3.08 & 13.5 & 1.7 \\
\hline $4 \mathrm{SDS}-4^{\mathrm{e}}$ & 0.40 & 30 & 0.92 & 0.14 & +80.6 & 2.4 & 18.00 & 3.01 & 15.2 & 1.9 \\
\hline \multicolumn{11}{|l|}{ Natural } \\
\hline $5 \mathrm{NDS}^{-1} \mathrm{1}^{\mathrm{f}}$ & 0.50 & 40 & 1.16 & 0.57 & +146.2 & 7.6 & 28.71 & 4.33 & 9.0 & 0.7 \\
\hline 6 NDS-2f & 0.50 & 40 & 1.45 & 0.80 & +121.7 & 6.6 & 21.97 & 3.73 & 13.5 & 1.4 \\
\hline 7 NDS-38 & 0.50 & 40 & 1.35 & 0.72 & +114.7 & 10.7 & 23.27 & 4.11 & 14.0 & 1.4 \\
\hline
\end{tabular}

a Piperidine $\mathrm{N}$-sulfonic acid.

b Measured in $\mathrm{H}_{2} \mathrm{O}(c=1)$.

c Determined by GPC.

d Degree of sulfation.

e Having 40\% mannose-branches.

f Branches: $1 \rightarrow 4,13 \% ; 1 \rightarrow 3,18 \%$.

g Branches: $1 \rightarrow 3,4 \%$ 
sulfated by the same procedure to give the sulfates. The degree of sulfation (DS) was $1.0-1.9$ for synthetic dextran sulfates and $0.7-1.4$ for sulfated natural dextrans by elemental analysis. The number average molecular weight $\left(\bar{M}_{n}\right)$ was in the range of $1.8 \times 10^{4}$ to $10.7 \times 10^{4}$ and the specific rotation $\left([\alpha]_{\mathrm{D}}^{25}\right)$ was higher than $+100^{\circ}$, except for mannose-branched dextran sulfate $\left(+80.6^{\circ}\right)$.

\section{Structure of Dextran Sulfates}

The ${ }^{13} \mathrm{C}$ NMR spectra of synthetic linear and mannose-branched dextran sulfates are shown in Figure 3 (A, No.4; B, No. 3 in Table III). The $\mathrm{C} 2$ and $\mathrm{C} 3$ peaks of the linear dextran sulfate (Figure 3B) shifted downfield by $4 \mathrm{ppm}$ in comparison with those of free dextran (Figure 2B), suggesting that the sulfate group was mainly introduced at $\mathrm{C} 2$ and $\mathrm{C} 3$ positions of the glucose unit. The mannose-branched dextran sulfate gave a complicated ${ }^{13} \mathrm{C}$ spectrum, as shown in Figure 3A. The absorptions of the mannose-branches, C3', C2', and $\mathrm{C}^{\prime}$ (seen in Figure 2A), almost disappeared and several new peaks appeared, as shown in Figure $3 \mathrm{~A}$. The $\mathrm{C} 2$ peak of the glucose unit in the main chain also shifted downfield by $4 \mathrm{ppm}$ after sulfation, indicating that the sulfate group was largely put into the branching mannose units and $\mathrm{C} 2$ position of the main chain.

The degree of substitution was determined by the ${ }^{1} \mathrm{H}$ NMR spectrum of the linear dextran sulfate $(S=13.5 \%, D S=1.7)$ as shown in Figure 4. From the H-H COSY measurement, the $\mathrm{H} 2$ proton shifted downfield by $4.4 \mathrm{ppm}$ after sulfation, suggesting that the hydroxyl group at $\mathrm{C} 2$ position was sulfated. The chemical shift of the sulfate-substituted proton generally shifted downfield due to the negative charge of the sulfate groups. The $\mathrm{H} 3$ proton appeared as two peaks around 4.6 and $4.1 \mathrm{ppm}$, indicating that lower field absorption should be due to the $\mathrm{C} 3$ sulfate-substituted unit and the higher field to the non-substituted one. It may be assumed that the sulfate group was

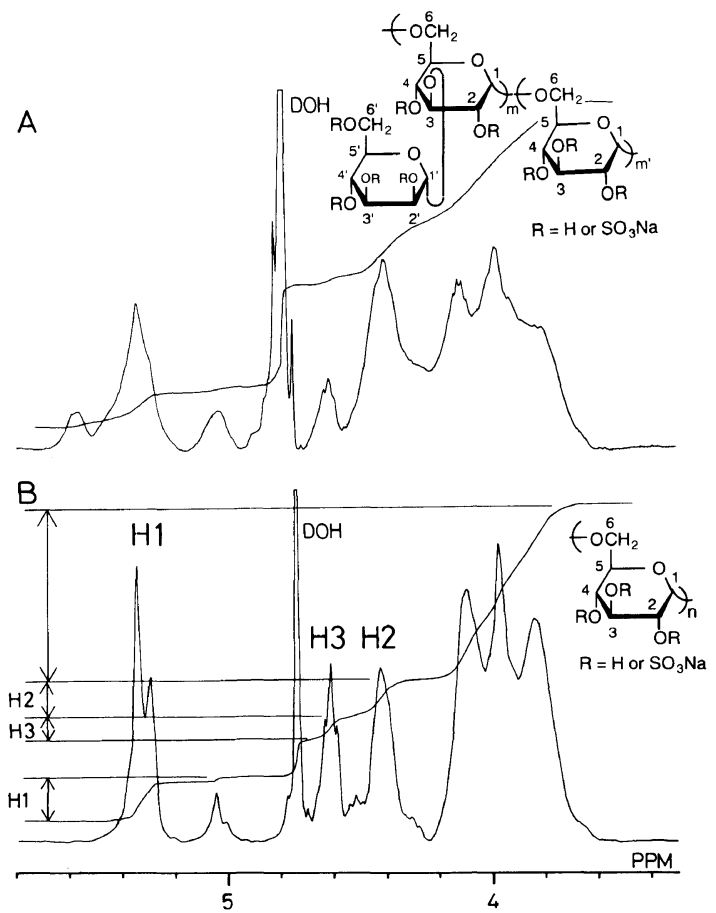

Figure 4. $400 \mathrm{MHz}{ }^{1} \mathrm{H}$ NMR spectra of (A) mannosebranches dextran sulfate (No. 4 in Table III) and (B) linear dextran sulfate (No. 3 in Table III) $\left(\mathrm{D}_{2} \mathrm{O}\right.$ as solvent at $37^{\circ} \mathrm{C}$ ).

introduced into the $\mathrm{H} 2$ position in the ratio of approximately $100 \%$ and the $\mathrm{H} 3$ about $50 \%$, which was calculated from the intensity of the respective $\mathrm{H} 2$ and $\mathrm{H} 3$ protons in Figure 4B (No. 3 in Table III). It was also speculated that in the linear dextran sulfate, the $\mathrm{H} 4$ position was substituted sulfate groups in the ratio of about $20 \%$, taking into account $D S=1.7$. In Figure 4A (No. 4 in Table III), the ${ }^{1} \mathrm{H}$ spectrum of the mannose-branched dextran sulfate was too complicated to analyze the structure. One mannose unit was attached to the glucose unit at $\mathrm{C} 3$ position of the main chain in the ratio of one branch in roughly two glucose units. Since the branches should be lower sterical less hindered than the main chain glucose unit, the sulfate group might have been easily introduced into the branching mannose unit.

\section{Anti-AIDS Virus Activity of Dextran Sulfates} Anti-AIDS virus activity of the dextran 


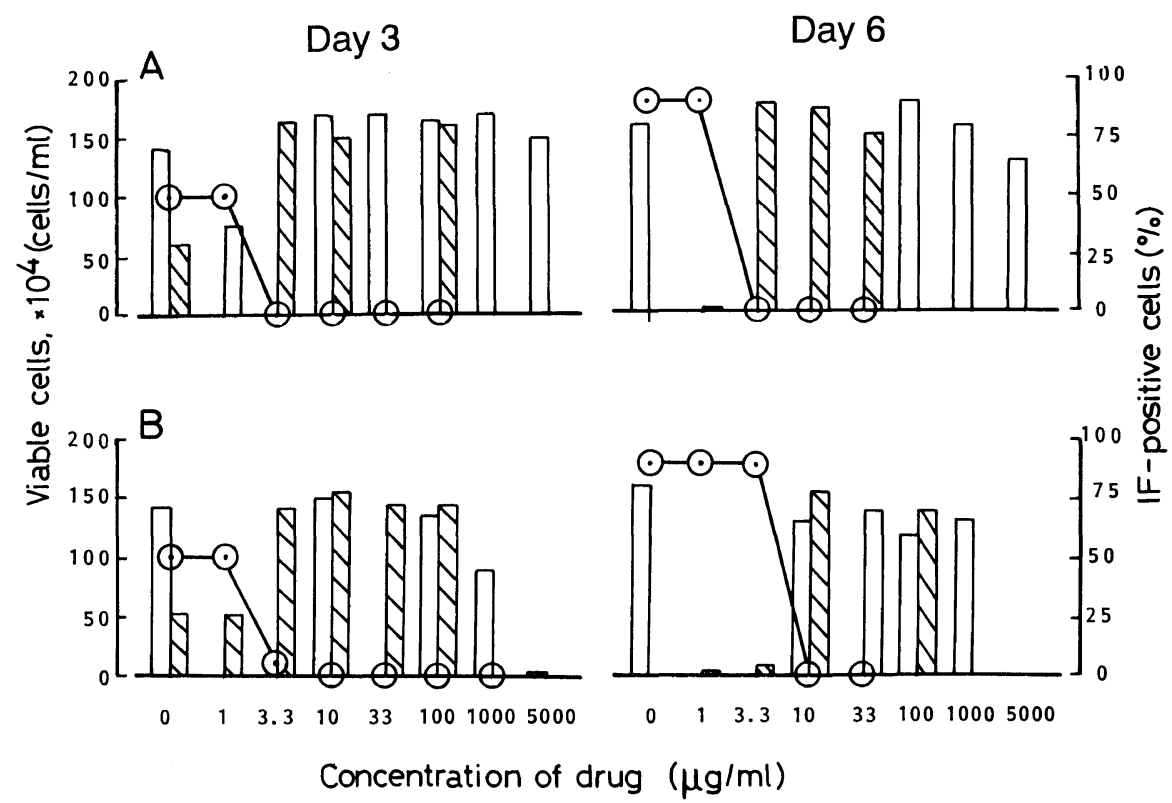

Figure 5. Inhibitory effects of dextran sulfates on cell growth and HIV-induced cytophathic effects. (A) Linear dextran sulfate $\left(S=13.5 \%, \bar{M}_{n}=1.8 \times 10^{4}\right)$ and (B) mannose-branches dextran sulfate $\left(S=15.2 \%, \bar{M}_{n}=2.4 \times 10^{4}\right)$. Key: open bars, MT-4 cells; slash bars, MT-4 cells and HIV-infected cells $(0.2 \%)$; open circles, percentage of IF-positive cells determined by counting the IF-positive cells per approximately 500 cells after 3 and 6 days of infection.

Table IV. Anti-AIDS virus activity of dextran sulfates

\begin{tabular}{|c|c|c|c|c|c|}
\hline \multirow{2}{*}{$\begin{array}{c}\text { Dextran } \\
\text { sulfate } \\
\text { No. }\end{array}$} & \multirow{2}{*}{$\frac{\text { S content }}{\%}$} & \multirow{2}{*}{$D S^{\mathbf{a}}$} & \multirow{2}{*}{$\frac{\bar{M}_{n}^{\mathrm{b}}}{\times 10^{4}}$} & \multirow{2}{*}{$\frac{E C_{100}{ }^{\mathrm{c}}}{\mu \mathrm{g} \mathrm{ml}^{-1}}$} & \multirow{2}{*}{$\frac{\mathrm{AA}^{\mathrm{d}}}{\text { unit } \mathrm{mg}^{-1}}$} \\
\hline & & & & & \\
\hline \multicolumn{6}{|l|}{ Synthetic } \\
\hline 1 SDS-1 & 12.4 & 1.0 & 4.0 & 3.3 & \\
\hline 2 SDS-2 & 12.4 & 1.2 & 4.2 & 3.3 & 49 \\
\hline 3 SDS-3 & 13.5 & 1.7 & 1.8 & 3.3 & 59 \\
\hline 4 SDS- $4^{e}$ & 15.2 & 1.9 & 2.4 & 10 & 85 \\
\hline \multicolumn{6}{|l|}{ Natural } \\
\hline 5 NDS- $1^{\mathrm{f}}$ & 9.0 & 0.7 & 7.6 & $>5000$ & \\
\hline 6 NDS-2 $2^{f}$ & 13.5 & 1.4 & 6.6 & 10 & 56 \\
\hline 7 NDS-3 & 14.0 & 1.4 & 10.7 & 3.3 & \\
\hline \multicolumn{6}{|c|}{ Reference dextran sulfate } \\
\hline NC-1032 & 18.4 & & 0.7 & 100 & 20.6 \\
\hline
\end{tabular}

a Piperidine $N$-sulfonic acid.

b Determined by GPC.

c Minimum concentration for $100 \%$ inhibition of antigen expression in 6 day culture.

d Anticoagulant activity.

e Having 50\% mannose-branches.

f Branches: $1 \rightarrow 4,13 \% ; 1 \rightarrow 3,18 \%$.

g Branches: $1 \rightarrow 3,4 \%$. 
sulfates in vitro was assayed by the prevention of HIV-induced cytophatic effects (CPE) and of virus-specific antigen expression using MT-4 cell line. The number of viable cells and ratio of antigen-positive cells were measured by the trypan blue dye exclusion method and indirect immunofluorescence (IF), respectively. The details appear in the previous paper. ${ }^{15}$ Since the number of viable cells cultivated in the presence of AIDS viruses was almost the same as that in the absence, synthetic linear and mannose-branched dextran sulfates at concentrations of 3.3 and $10 \mu \mathrm{g} \mathrm{ml}^{-1}$ had potent inhibitory effects against AIDS-virus infection (Figure 5). No IF-positive cells were detected at these concentrations, indicating both dextran sulfates to block completely virus infection after 6 day cutivation in vitro. For synthetic and natural dextran sulfates prepared in this experiment, the minimum effective concentration $\left(E C_{100}\right)$ for $100 \%$ inhibition on HIV infection in 6-day culture is shown in Table IV. Dextran sulfate with low $D S$ of 0.7 (No. 5) showed no anti-AIDS virus activity. It was found that dextran sulfates with more than $D S$ of 1.0 synthesized here had potent activity showing $E C_{100}$ of 3.3 or $10 \mu \mathrm{g} \mathrm{ml}^{-1}$. The anticoagulant activity (AA), an important biological activity intrinsic to sulfated polysaccharides, was measured using bovine plasma according to a modification of the United State Pharmacopoeia. ${ }^{22}$ Dextran sulfates synthesized in this experiment had higher anti-

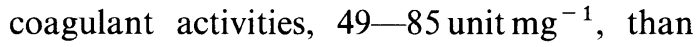
that (20.6 unit $\mathrm{mg}^{-1}$ ) of a commercial dextran sulfate (Meito Sangyo NC-1032). In particular, synthetic dextran with mannose-branches showed the highest anticoagulant activity of

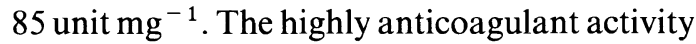
may be ascribed to the flexible polymer backbone and high degree of sulfation of the branched dextran sulfate.

\section{DISCUSSION}

As shown in Table IV, dextran sulfates with
DS higher than 1.0 and $\bar{M}_{n}=1.8 \times 10^{4}$ had $100 \%$ inhibitory effects against HIV infection $\left(E C_{100}\right)$ at 3.3 or $10 \mu \mathrm{g} \mathrm{ml}^{-1}$. The No. 5 dextran sulfate with low $D S$ of 0.7 exhibited no anti-AIDS virus activity. Although there were 3 hydroxyl groups in a glucose residue of the main chain, the hydroxyl group at the 2 position may be first substituted by the sulfate group, which was revealed by NMR measurement. Thus, to obtain high anti-AIDS virus activity, the 1,6- $\alpha$ linked dextran sulfate may require the fully sulfate-substituted 2 position. However, dextran sulfate having a sulfate group at $\mathrm{C} 3$ or $\mathrm{C} 4$ position has not been obtained yet, and a detailed discussion on the sulfate substituents could not be given here. The relationship between the positions of sulfate-substituents and anti-AIDS virus activity is under investigation. For $1,3-\beta$ linked curdlan sulfate to acquire high activity, the substitution at 6 position is important. ${ }^{23,} 24$

Cytotoxicity and anti-AIDS virus activity were measured at the same time using MT-4 cells as shown in Figure 5. Figure 5A shows no cytotoxicity above $5000 \mu \mathrm{g} \mathrm{ml}^{-1}$ of linear dextran sulfate (No. 3 in Table 4). The cytotoxicity of the mannose-branched dextran sulfate was higher than that of the linear one, because former killed almost all cells during 3 days of culture (Figure 5B). Possibly due to too highly sulfate-substituted branches.

These dextran sulfates had high blood anticoagulant activity. The anticoagulant activity would be a side effect for anti-AIDS virus activity, because high anticoagulant dextran sulfate strongly interacted with the blood coagulation proteins in plasma and thus selective interaction to AIDS virus may not accure. Recently, Dextran sulfate has almost no effect as AIDS drug by an oral administration, although no significant side effects were observed. ${ }^{25}$ Consequently, it was revealed that a possibility of dextran sulfate as an anti-AIDS virus drug in vivo may be low. However, it was reported recently that cyclical and low molecular weight polysaccharides such as 
sulfated cyclodextrins ${ }^{27}$ and low molecular weight dextran sulfates $\left(\bar{M}_{w}=1000\right)^{18}$ show potent anti-AIDS virus activity in some assay systems. Since the anticoagulant activity of the low molecular weight samples was lower than that of higer ones, it may be possible to use the low molecular weight dextran sulfates as anti-AIDS virus drugs by an intravenous administration. It is relatively easy to obtain low molecular weight dextran sulfates by complete chemical synthesis.

Lentinan $^{26}$ and curdlan sulfates ${ }^{23,24}$ hold promise as anti-AIDS virus drugs, because the curdlan sulfate has potent anti-AIDS virus activity but low cytotoxicity and low anticoagulant activity. For curdlan sulfate, administration by an intravenous injection was started to check its toxicity toward humans.

Acknowledgment. The authors are grateful to Mr. T. Mimura and Mr. Y. Kaneko of Ajinomoto Co., Inc. for valuable discussions and for measurement of elemental analysis.

\section{REFERENCES AND NOTES}

1. C. R. Ricketts, Biochemistry, 51, 129 (1951).

2. G. Oshima, T. Nagai, and K. Nagasawa, Thrombosis Res., 35, 601 (1984).

3. T. Uryu, in S. Penczek, Ed., "Models of Biopolymers by Ring-Opening Polymerization," CRC Press, Boca Raton, Florida, 1990, p. 133.

4. E. R. Ruckel and C. Schuerch, J. Org. Chem., 31, 2233 (1966).

5. T. Uryu and C. Schuerch, Macromolecules, 4, 342 (1971).

6. T. Uryu and M. Yamanaka, M. Henmi, K. Hatanaka, and K. Matsuzaki, Carbohydr. Res., 157, 157 (1986).

7. K. Hatanaka, T. Hirobe, T. Yoshida, M. Yamanaka, and T. Uryu, Polym. J., 22, 435 (1990).

8. M. Torii, S. Ogawa, K. Watanabe, T. Koshikawa, M. Yamazoe, T. Uryu, and C. Schuerch, J. Biochem., 99, 263 (1986).

9. B. Ehlers, R. Rudolph, and H. Diringer, J. Gen.
Virol., 65, 423 (1984).

10. H. Diringer, Jpn. Patent (Tokkai Sho) 62-215529 (1987).

11. R. Ueno and S. Kuno, Lancet, 1379 (1987).

12. H. Nakashima, O. Yoshida, T. Tochikura, T. Yoshida, T. Mimura, Y. Kido, Y. Motoki, Y. Kaneko, T. Uryu, and N. Yamamoto, Jpn. J. Cancer Res., 78, 1164 (1987).

13. H. Mitsuya, D. J. Looney, S. Kuno, R. Ueno, F. Ueno, F. W. Stall, and S. Broder, Science, 240, 646 (1988).

14. M. Baba, R. Pauwels, J. Balzarini, J. Arnout, J. Desmyter, and E. De Clercq, Proc. Natl. Acad. Sci. U.S.A., 85, 6132 (1988).

15. H. Nakashima, O. Yoshida, M. Baba, E. De Clercq, and N. Yamamoto, Antiviral Res., 11, 233 (1989).

16. N. R. Hartman, D. G. Johns, and H. Mitsuya, AIDS Res. Hum. Retroviruses, 6, 805 (1990).

17. L. N. Callahan, M. Phelan, M. Mallinson, and M. A. Norcross, J. Virol., 65, 1543 (1991).

18. M. Witvrouw, D. Schols, G. Andrei, R. Snoeck, M. Hosoya, R. Pauwels, J. Balzarini, and E. De Clercq, Antiviral Chem. Chemother., 2, 171 (1991).

19. (a) J. Zachoval and C. Schuerch, J. Am. Chem. Soc., 91, 1165 (1969).

(b) C. Schuerch and T. Uryu, Macromolecular Synth., 4, 151 (1972).

20. G. H. Hakimelahi, Z. A. Proba, and K. K. Ogilvie, Tetrahedron Lett., 4775 (1981).

21. D. Gagnaire and M. Vignon, Makromol. Chem., 178, 2321 (1977).

22. U. S. Pharmacopeia National Formulary, USP XXI, 1985.

23. Y. Kaneko, O. Yoshida, R. Nakagawa, T. Yoshida, M. Date, S. Ogihara, S. Shioya, Y. Matsuzawa, N. Nagashima, Y. Irie, T. Mimura, H. Shinkai, N. Yasuda, K. Matsuzaki, T. Uryu, and N. Yamamoto, Biochem. Pharmacol., 39, 793 (1990).

24. T. Yoshida, K. Hatanaka, T. Uryu, Y. Kaneko, E. Suzuki, H. Miyano, T. Mimura, O. Yoshida, and N. Yamamoto, Macromolecules, 23, 3717 (1990).

25. K. J. Lorentsen, C. W. Hendrix, J. M. Collins, D. M. Kornhauser, B. G. Petty, R. W. Kecker, C. Flexner, and R. H. Eckel, Ann. Intern. Med., 111, 561 (1989).

26. K. Hatanaka, T. Yoshida, T. Uryu, O. Yoshida, H. Nakashima, N. Yamamoto, T. Mimura, and Y. Kaneko, Jpn. J. Cancer Res., 80, 95 (1989).

27. T. Moriya, H. Kurita, K. Matsumoto, T. Otake, H. Mori, M. Moromoto, N. Ueba, and N. Kunita, J. Med. Chem., 34, 2301 (1991). 